\title{
PENGARUH EARNING PER SHARE (EPS) DAN PRICE BOOK VALUE (PBV) TERHADAP HARGA SAHAM PADA INDUSTRI RETAIL YANG TERDAFTAR DI BEI PERIODE 2013-2016
}

\author{
Hana Tamara Putri \\ Dosen Fakultas Ekonomi Universitas Batanghari
}

\begin{abstract}
The purpose of this studyis to find out how the influence of earnings per share (EPS) and price book value $(P B V)$ simultaneously and parcial to stock prices in retail industry listed on the Stock Exchange Indonesia period 2013-2016. The ojek this analysis is the retail industry listed on the stock exchange indonesia period 2013-2016. Sampel used in this research is as many as 8 retail industry listed on the Stock Exchange Indonesia period 2013-2016. The method used is qualitative and quantitative method. . The analytical tool used in this research is multiple linear regression analysis, the classical assumption test (normality, multicolinearity, hetoroscedasicity, and autocorrelation) and coefficient of determination. Based on the results of multiple linear regression analysis showed the equation $\log Y=2.244+\log 0,528 E P S-\log 0,018 P B V+e$, with $F$ test value of 5,153. Value t test for earning per share (EPS) of 3,159 and the value of T test for price book value $(P B V)$ of 0,113. Rated $R$ Square 26,2\%, while the remaining 73,8\% explained other factors beyond the study models. And the $R$ value of 0,512. The conclusion of this research indicates that simultaneously independent variable earnings per share (EPS) and price book value (PBV) have an effect on stock price variable. The parcial price $(P B V)$ has no significant effect on stock price dependent and earnings per share (EPS) have a significant effect on stock price variables.
\end{abstract}

Keyword : earning per share (EPS), price book value (PBV)

\section{PENDAHULUAN}

Pada era globalisasi seperti sekarang ini persaingan di dunia usaha semakin berkembang. Semakin banyaknya perusaaan baru yang muncul yang bersaing dengan perusahaan lama. Tujuan perusahaan adalah ingin menjalankan usahanya dalam waktu yang lama. Selain itu tujuan perusahaan adalah mencari laba besarnya untuk kesejahteraan karyawannya dan perusahaan itu sendiri. Persaingan yang semakin ketat, perusahaan harus melakukan segala cara untuk terus tumbuh dan berkembang, agar terus tumbuh dan berkembang tidaklah hal yang mendorong perusahaan untuk mencari sumber pembiayaan yang dapat menyediakan dana dengan jumlah yang cukup besar yang digunakan untuk mengembangan usaha, peningkatan produksi dan kegiatan perusahaan lainnya.

Keberhasilan perusahaan dapat dilihat dari laju pertumbuhan yang tinggi dimana pertumbuhan tersebut memerlukan dukungan tambahan investasi. Salah satu alternatif pilihan diambil perusahaan dalam memperoleh dana tambahan dan dengan menjual surat-surat berharga, apakah dalam bentuk saham, obligasi ataupun surat berharga lainnya. Untuk melakukan kegiatan perdagangan saham maka diperlukan pasar modal. Pasar modal merupakan pasar untuk berbagai instrumen keuangan jangka panjang yang bisa diperjual belikan, baik dalam bentuk hutang, ekuitas (saham) instrumen derivatif, maupun instrumen lainnya. (Adisetiawan, 2015)

Undang-undang No. 8 Tahun 1995 tentang pasar modal, instrumen pasar modal adalah semua surat berharga (efek) yang paling umum diperjual belikan melalui pasar modal. Instrumen yang paling umum diperjual belikan melalui Bursa Efek Indonesia (BEI) adalah saham, obligasi, right dan warant. Manfaat pasar modal yang berkembang nantinya akan lebih mendorong tumbuhnya lembaga-lembaga penunjang pasar modal lainnya yang belum ada sekarang. Bursa Efek Indonesia (BEI) merupakan sebuah pasar yang berhubungan dengan pembelian dan penjualan efek perusahaan yang sudah terdaftar di bursa. Bursa efek tersebut, bersama-sama dengan pasar uang merupakan sumber utama permodalan eksternal bagi perusahaan dan pemerintahan. (Adisetiawan dan Asmas, 2012)

Untuk dapat mengetahui kinerja suatu perusahaan dapat dilihat dari aspek keuangan dengan cara melihat dari laporan keuangan perusahaan yang merupakan salah satu informasi untuk menganalisa keadaan

Pengaruh Earning Per Share (EPS) dan Price Book Value (PBV) terhadap Harga Saham pada Industri Retail yang Terdaftar di BEI Periode 2013-2016 
atau posisi keuangan perusahaan. Laporan keuangan diharapkan dapat memberikan hasil usaha yang telah dicapai secara kuantitatif pada semua pihak yang berkepentingan dengan perusahaan itu. Rasio keuangan secara garis besar dikelompokkan menjadi lima rasio yaitu rasio likuiditas, rasio aktivitas, rasio profitabilitas, rasio solvabilitas (leverage) dan rasio pasar. Rasio likuiditas (liquidity ratio) merupakan kemampuan suatu perusahaan memenuhi kewajiban jangka pendeknya secara tepat waktu adapun bagian dari rasio likuiditas yaitu current ratio $(\mathrm{CR})$, quick ratio $(\mathrm{QR})$, net working capital ratio dan cash flow liquidity ratio. (Fahmi, 2014:66).

Rasio aktivitas (activity ratio) adalah rasio yang menggambarkan sejauh mana suatu perusahaan mempergunakan sumber daya yang dimilikinya guna menunjang aktivitas perusahaan dimana penggunaan aktivitas ini dilakukan secara sangat maksimal dengan maksud memperoleh hasil yang maksimal. Adapun bagian dari rasio aktivitas ini adalah inventory turnover (ITO), fixed asset turnover (FATO) dan total asset turnover (TATO). (Fahmi, 2014:77-84). Pada penelitian ini rasio yang digunakan adalah rasio pasar. Rasio pasar merupakan sekumpulan rasio yang menghubungkan harga saham dengan laba dan nilai buku per saham. Rasio ini memberikan petunjuk mengenai apa yang dipikirkan investor atas kinerja perusahaan di masa lalu serta prospek di masa mendatang (Moeljadi, 2006:75). Rasio pasar yang digunakan adalah earning per share (EPS), dan price book value (PBV). Earning per share (EPS) adalah bentuk pemberian keuntungan yang diberikan kepada pemegang saham dari setiap lembar saham yang dimiliki (Fahmi, 2014:83). Earning per share (EPS) merupakan salah satu rasio keuangan yang sering digunakan oleh investor untuk menganalisa kemampuan perusahaan menghasilkan laba, sehingga semakin besar Earning Per Share (EPS) maka investor akan tertarik untuk melakukan investasi pada perusahaan tersebut. Oleh karena itu, hal tersebut akan mengakibatkan permintan akan saham meningkat dan harga saham akan meningkat.

Price Book Value ditunjukkan dalam perbandingan antara harga saham terhadap nilai bukunya. Price Book Value digunakan untuk melihat ketidak wajaran harga saham. Price Book Value yang rendah menunjukkan harga sahamnya murah, jika posisi harga saham berada dibawah book value ada kecenderungan harga saham tersebut akan menuju keseimbangan minimal sama dengan nilai bukunya. Hal ini berarti harga saham itu berpotensi lebih besar untuk naik, sehingga return yang diterima akan meningkat. Base Price (Harga dasar) yaitu harga perdana dari suatu saham dan Market Price (Harga pasar) yaitu harga penutup (closing price) dari suatu saham jadi harga pasar ini la yang menentukan naik turunnya suatu saham. Pada penelitian ini harga saham yang digunakan adalah harga penutupan (Closing Price).

Industri retail merupakan salah satu bisnis yang sedang memiliki prospek yang sangat bagus baik itu di negara maju maupun negara berkembang. Pada perkembangannya, kini bisnis retail di Indonesia mulai bertransformasi dari bisnis retail tradisional menuju bisnis retail modern. Perkembangan bisnis retail di Indonesia sudah semakin menjamur dihampir seluruh wilayah Indonesia. Hal tersebut dapat terlihat dari banyaknya toko retail modern yang membuka cabang di berbagai wilayah Indonesia. Retailing merupakan suatu usaha bisnis yang berusaha memasarkan barang dan jasa kepada konsumen akhir yang menggunakannnya untuk keperluan pribadi dan rumah tangga.

Berikut ini adalah perkembangan earning per share (EPS) dan price book value (PBV) pada industri retail yang terdaftar di Bursa Efek Indonesia (BEI) periode 2013-2016 yang terlihat pada Tabel 1.

\section{Tabel 1}

Perkembangan Earning Per Share (EPS) Pada Industri Retail yang Terdaftar di BEI periode 20122016 (dalam satuan rupiah)

\begin{tabular}{llrrrrr}
\multirow{2}{*}{ No } & \multicolumn{1}{c}{ Nama Emiten } & \multicolumn{2}{c}{ Tahun } \\
& & $\mathbf{2 0 1 3}$ & $\mathbf{2 0 1 4}$ & $\mathbf{2 0 1 5}$ & $\mathbf{2 0 1 6}$ & \multicolumn{2}{c}{ Rerata } \\
\hline 1 & PT. Ace Hardware Indonesia, Tbk & 19,88 & 26,88 & 24,05 & 22,55 & 23,34 \\
2 & PT. Catur Sentosa Adiprana, Tbk & 7,32 & 17,76 & 28,37 & 39,56 & 23,25 \\
3 & PT. Erajaya Swasemba, Tbk & 8,32 & 13,08 & 6,99 & 6,86 & 8,81 \\
4 & PT. Midi Utama Indonesia, Tbk & 22,69 & 24,70 & 16,00 & 18,09 & 20,37 \\
5 & PT. Matahari Putra Prima, Tbk & 40,12 & 56,83 & 168,74 & 55,89 & 80,39 \\
6 & PT. Mitra Adiperkasa, Tbk & 23,45 & 34,76 & 53,63 & 183,29 & 73,78
\end{tabular}


$7 \quad$ PT. Ramayana Lestari Sentosa, Tbk

8 PT. Sumber Alfaria Trijaya, Tbk

Rata-Rata Industri

31,55

12,38

44,98

13,62

53,39

17,59

15,71

Perkembangan

172,59

231,37

364,79

54,05

34,05

57,66

397,88

45,99

291,65

Sumber: Laporan Keuangan Industri Retail Periode 2013-2016

\section{Landasan Teori \\ Rasio Keuangan}

Menurut Kasmir (2008:364) rasio keuangan merupakan rasio yang digunakan untuk mengukur apakah permodalan yang dimiliki sudah memadai atau sejauh mana penurunan yang terjadi dalam total aset yang masuk dapat ditutupi oleh capital equity. Berdasarkan tujuannya rasio dibagi menjadi 5 yakni :

1. Rasio likuiditas adalah rasio yang menggambarkan kemampuan suatu perusahaan untuk melunasi semua kewajiban yang harus segera di penuhi (hutangjangka pendeknya). Adapun bagian dari rasio likuiditas yaitu current ratio $(\mathrm{CR})$, quick ratio $(\mathrm{QR})$, net working capital ratio dan cash flow liquidity ratio. (Fahmi, 2014:66),

2. Rasio Leverage, rasio yang menunjukkan kemampuan perusahaan dalam memenuhi segala kewajibannya baik jangka pendek maupun jangka panjang apabila perusahaan di likuidasi. Bagian dari rasio solvabilitas adalah debt to asset ratio (DAR), debt to equity ratio (DER), time interest earned, cash flow coverage, long-term debt to total capitalization dan fixed charge coverage. (Fahmi, 2014:72-76)

3. Rasio profitabilitas, rasio yang digunakan untuk mengukur kemampuan suatu perusahaan dalam mendapatkan laba. Bagian dari rasio ini adalah gross profit margin (GPM), net profit margin (NPM), return on investment (ROI) dan return on equity (ROE). (Fahmi, 2014:78).

4. Rasio aktivitas, rasio yang melihat pada beberapa asset kemudian menentukan berapa tingkat aktivitas aktiva-aktiva tersebut pada tingkat kegiatan tertentu.Adapun bagian dari rasio aktivitas ini adalah inventory turnover (ITO), fixed asset turnover (FATO) dan total asset turnover (TATO) (Fahmi, 2014:77).

5. Rasio pasar

Merupakan sekumpulan rasio yang menghubungkan harga saham dengan laba dan nilai buku per saham. Menurut Fahmi (2011:83) adapun rumus yang digunakan untuk mengukur rasio likuiditas adalah sebagai berikut:

a. Earning Per Share (EPS)

EPS atau pendapatan perlembar saham adalah bentuk pemberian keuntungan yang diberikan kepada para pemegang saham dari setiap lembar saham yang dimiliki. Rumusnya adalah:

\section{Price Book Value (PBV)}

$$
\mathrm{EPS}=\frac{\text { Pendapatan Setelah Pajak }}{\text { Jumlah Saham Beredar }}
$$

Price Book value (PBV) menurut Fahmi (2016:83) adalah rasio untuk mengukur seberapa besar harga saham yang ada dipasar dibandingkan dengan nilai buku sahamnya. Rumus PBV adalah sebagai berikut:

$$
\mathrm{PBV}=\frac{\text { Market price per share }}{\text { book value per share }} \times 100
$$

\section{Faktor-faktor yang mempengaruhi keberhasilan pasar modal}

1. Suplly sekuritas, faktor ini berarti harus banyak perusahaan yang bersedia menerbitkan sekuritas di pasar modal.

2. Demand akan sekuritas, faktor ini berarti bahwa harus terdapat anggota masyarakat yang memiliki jumlah dana yang cukup besar untuk dipergunakan membeli sekuritas di pasar modal.

3. Kondisi politik dan ekonomi, faktor ini akhirnya akan mempengaruhi supply dan demand akan sekuritas. Kondisi politik yang stabil akan ikut membantu pertumbuhan ekonomi yang akhirnya mempengaruhi supply dan demand akan sekuritas. 
4. Masalah hukum dan peraturan, pembeli sekuritas pada dasarnya mengandalkan diri pada informasi yang disediakan oleh perusahaan-perusahaan yang menerbitkan sekuritas. Kebenaran informasi, karena itu menjadi sangat penting, disamping kecepatan dan kelengkapan informasi. Peraturan yang melindungi pemodal dari informasi yang tidak benar dan menyesatkan menjadi mutlak diperlukan.

5. Keberadaan lembaga yang mengatur dan mengawasi kegiatan pasar modal dan berbagai lembaga yang memungkinkan dilakukan transaksi secara efisien. Kegiatan di pasar modal pada dasarnya merupakan kegiatan yang dilakukan oleh pemilik dana dan pihak yang memerlukan dana secara langsung (artinya tidak ada perantara keuangan yang mengambil alih risiko investasi).

\section{Saham}

Hendy (2008:175) mengemukakan definisi saham adalah bukti penyertaan modal di suatu perusahaan, atau merupakan bukti kepemilikan atas suatu perusahaan saham juga menjadi dasar ke ikutsertaan pemegangnya dalam menentukan para pengelola perusahaan, seperti komisaris dan direktur. Perusahaan dapat menerbitkan lebih dari satu jenis sahams, misalnya saham biasa (Common Stock) dan saham preferensi (Prefered Stock).

\section{Harga Saham}

Menurut Kasmir (2012:29, laba adalah selisih dari jumlah pendapatan yang lebih besar daru jumlah biaya. Keberhasilan suatu perusahaan dapat dilihat dari tingkat laba yang diperoleh perusahaan itu sendiri karena tujuan utama perusahaan adalah memperoleh laba yang sebesar-besarnya. Harga saham merupakan harga yang sedang berlaku di pasar efek yang ditentukan oleh kekuatan pasar dalam artian tergantung pula kekuatan permintaan (penawaran) dan penawaran (permintaan jual). Harga pasar saham juga menunjukkan nilai dari perusahaan itu sendiri. Semakin tinggi nilai dari harga pasar saham suatu perusahaan, maka investor akan tertarik menjual sahamnya. Bursa saham merupakan salah satu indikator perekonomian suatu Negara maka diperlukan suatu perhitungan tentang transaksi yang terjadi dalam bursa sepanjang periode tertentu.

\section{Faktor-faktor yang Mempengaruhi Harga Saham}

Menurut Arifin (2004) faktor-faktor yang mempengaruhi harga saham adalah sebagai berikut:

1. Kondisi fundamental emiten

Faktor fundamental adalah faktor yang berkaitan langsung dengan kinerja emiten itu sendiri.

2. Hukum penawaran dan permintaan

Faktor hukum penawaran dan permintaan berada diurutan kedua setelah faktor fundamental karena begitu investor tau kondisi fundamental perusahaan tentunya mereka akan melakukan transaksi baik jual maupun beli.

3. Tingkat suku bunga

Dengan adanya perubahan suku bunga, tingkat pengembalian hasil berbagai sarana investasi akan mengalami perubahan. Bunga yang tinggi akan berdampak pada alokasi dana investasi pada investor.

4. Valuta asing

Mata uang Amerika (Dollar) merupakan mata uang terkuat diantara mata uang yang lain. Apabila dollar naik maka investor asing akan menjual sahamnya dan ditempatkan di bank dalam bentuk dollar, sehingga menyebabkan harga saham akan turun.

5. Dana asing dibursa

Mengamati jumlah dana investasi asing meurpakan hal yang pentingm karena demikian besarnya dana yang ditanamkan, hal ini menandakan bahwa kondisi investasi di Indonesia telah kondusif yang berarti pertumbuhan ekonomi tidak lagi negatif, yang tentu saja akan merangsang kemampuan emiten untuk mencetak laba.

6. Indeks harga saham

Kenaikan indeks harga saham gabungan sepanjang waktu tertentu, tentunya mendatangkan kondisi investasi dan perekonomian negara dalam keadaan baik. Sebaliknya jika turun berarti iklim investasi sedang buruk. Kondisi demikian akan mempengaruhi naik atau turunnya harga saham di pasar bursa.

Pengaruh Earning Per Share (EPS) dan Price Book Value (PBV) terhadap Harga Saham pada Industri Retail yang Terdaftar di BEI Periode 2013-2016 


\section{Hubungan Antar Variabel}

\section{Hubungan Antara Earning Per Share (EPS) terhadap Harga Saham}

Earning Per Share (EPS) merupakan perbandingan antara laba bersih dengan jumlah saham yang beredar. Secara parsial Earning Per Share (EPS) memberikan pengaruh paling besar terhadap harga saham karena earning per share (EPS) merupakan rasio yang cukup penting bagi para investor (Ardiyanto:2007). Semakin besar earning per share (EPS) maka investor akan tertarik untuk melakukan investasi pada perusahaan tersebut. Oleh karena itu, hal tersebut akan mengakibatkan permintaan akan saham meningkat dan harga saham meningkat.

\section{Hubungan Antara Price Book Value (PBV) terhadap Harga Saham}

Price Book Value (PBV) yaitu salah satu indikator utama untuk melihat apakah suatu saham mahal atau tidak. Oleh sebab itu price book value (PBV) sangat berpengaruh terhadap harga saham (Fahmi, 2011:85).

Berdasarkan uraian diatas, maka hipotesis dalam penelitian ini adalah sebagai berikut: diduga Earning Per Share (EPS) dan Price Book Value (PBV) secara simultan dan parsial berpengaruh signifikan terhadap harga saham pada Industri Retail Periode 2013-2016.

\section{METODE}

Dalam penelitian ini data yang digunakan adalah jenis data sekunder. Data sekunder merupakan data yang tidak langsung memberikan data kepada pengumpul data, misalnya lewat orang lain atau lewat dokumen (Sugiyono, 2017:137). Pada penelitian ini data yang dikumpulkan berupa laporan tahunan Industri Retail yang terdaftar di Bursa Efek Indonesia (BEI) yang diambil melalui situs www.idx.co.id. Populasi yang digunakan dalam penelitian ini adalah industri retail yang terdaftar dan telah melakukan pelaporan keuangannya di Bursa Efek Indonesia (BEI) selama periode tahun 2012-2016 sebanyak 22 perusahaan yang terdaftar di BEI. Berikut ini nama-nama industri retail yang terdaftar di BEI. Sampel menurut Sugiyono (2017:81) merupakan bagian dari jumlah dan karakteristik yang dimiliki oleh populasi tersebut. Kriteria penarikan sampel pada penelitian ini adalah: 1). Emiten yang tergabung dalam Industri Retail selama periode penelitian 2013-2016; dan 2). Memiliki data yang lengkap selama periode 2013-2016._Dalam penelitian ini menggunakan metode pengumpulan data dengan cara penelitian kepustakaan (Library Research).

\section{Analisis Regresi Linear Berganda}

Untuk mengetahui apakah rasio keuangan berpengaruh terhadap laba bersih dan seberapa besar pengaruhnya maka digunakan analisis regresi linear berganda, adapun persamaan dari regresi linear berganda dalam penelitian ini adalah sebagai berikut:

$\mathbf{Y}=\boldsymbol{\alpha}+\boldsymbol{\beta}_{1} \mathbf{x}_{1}+\boldsymbol{\beta}_{2} \mathbf{x}_{2}+\mathbf{e}$

Dimana: $\mathrm{Y}=$ Harga Saham; $\mathrm{X}_{1}=$ Earning Per Share $(\mathrm{EPS}) ; \mathrm{X}_{2}=$ Price Book Value $(\mathrm{PBV}) ; \alpha=$ Konstanta; $\beta_{1=} \beta_{2}=$ koefisien regresi; $\mathrm{e}=$ error

\section{Uji Normalitas}

Uji asumsi klasik normalitas, di mana akan menguji data variabel bebas $(\mathrm{X})$ dan data variabel terikat (Y) pada persamaan regresi yang dihasilkan, berdistribusi normal atau berdistribusi tidak normal. Persamaan regresi dikatakan baik jika mempunyai data variabel bebas dan data variabel terikat berdistribusi mendekati normal atau normal sama sekali. untuk mendeteksi normalitas dapat dilakukan dengan uji statistik, test statistik yang digunakan antara lain cara statistik, analisis normal probability plots (Sunyoto, 2013:92).

\section{Uji Multikolinearitas}

Uji multikolineritas bertujuan untuk menguji apakah pada model regresi yang digunakan ditemukan adanya korelasi antar variabel atau tidak. Model regresi yang baik seharusnya tidak terdapat korelasi antara variabel independen. Model regresi dikatakan bebas multikolinearitas jika Variance Inflation Factor (VIF) < 10, dan mempunyai angka tolerance $>0,01$. Jika korelasi antar variabel independent lemah (dibawah 0,05 ) maka dapat dikatakan bebas multikolinearitas. 


\section{Uji Autokorelasi}

Menurut Priyatno (2009:61) autokorelasi adalah keadaan dimana terjadinya korelasi dari residual untuk pengamatan satu dengan pengamatan lainnya yang disusun menurut runtut waktu.

\section{Uji Heteroskedastisitas}

Uji heteroskedastisitas ini bertujuan untuk menguji apakah dalam model regresi terjadi ketidaksamaan variance dan residual suatu pengamatan yang lain. Jika variance dan residual tetap maka disebut maka disebut homokedastisitas. Jika berbeda disebut heteroskedastisitas. Pengujian terhadap heteroskedastisitas dilakukan dengan melihat ada tidaknya pola tertentu pada grafik scatterplot.

\section{HASIL}

Uji normalitas dilakukan untuk mengetahui apakah data yang digunakan memiliki distribusi normal. Pengujian normalitas dilakukan dengan menggunakan P-P Plot Test. Uji Heteroskedasitas bertujuan untuk menguji apakah dari model regresi terjadi ketidaksamaan varians dari residual satu pengamatan ke pengamatan yang lain. Model regresi yang baik adalah yang homoskedasitas atau tidak terjadi heteroskedasitas. Salah satu cara mendeteksi ada atau tidaknya heteroskedasitas adalah dengan melihat grafik scatterplot antara lain prediksi variabel terikat dengan residualnya. Jika ada pola tertentu, seperti titik-titik menyebar di atas dan di bawah angka 0 pada sumbu Y, maka tidak terjadi heteroskedasitas. Multikolinearitas merupakan fenomena adanya korelasi yang sempurna antara satu variabel bebas dalam suatu model regresi linear berganda. Uji ini dilakukan dengan menggunakan VIF dengan kriteria, jika VIF suatu variabel bebas $>10$, maka dapat disimpulkan bahwa variabel bebas tersebut terjadi multikolinearitas. Uji Autokorelasi digunakan untuk melihat apakah pengaruh berdasarkan variabel-variabel dalam modelnya melalui selang waktu. Hasil pengujian dengan menggunakan alat analisis regresi berganda diperoleh Model regresi sebagai berikut : $\mathrm{Y}=2.244+0,528(\mathrm{EPS})-0,018(\mathrm{PBV})+\mathrm{e}$

Keterangan: $\mathrm{Y}=$ Harga saham; $\mathrm{X}_{1}=$ Earning per share $(\mathrm{EPS}) ; \mathrm{X}_{2}=$ Price book value $(\mathrm{PBV})$

\section{Pengujian Hipotesis}

Uji simultan digunakan untuk mengetahui apakah variabel independen secara simultan mempengaruhi variabel dependen. Hasil perhitungan menggunakan program spss dengan membandingkan $f_{\text {hitung }}$ dengan $f_{\text {tabel }}$ dengan taraf signifikan $\alpha=0,05 \mathrm{df}=19$. Dapat diketahui bahwa $\mathrm{f}_{\text {hitung }}$ sebesar 5,153 dengan membandingkan $\mathrm{f}_{\text {tabel }} \alpha=3,52$ dengan derajat bebas pembilang 2 dan derajat penyebutnya 19 , didapat $f_{\text {tabel }}$ sebesar 3,52. $F_{\text {hitung }}$ lebih besar dari $\mathrm{f}_{\text {tabel }}(5,153>3,52)$ berarti Ho ditolak $\mathrm{H}_{1}$ di terima, sehingga dapat dikatakan secara simultan variabel independen earning per share (EPS) dan price book value (PBV) berpengaruh terhadap variabel dependen harga saham. Pengujian ini dilakukan untuk mengetahui tingkat signifikan pengaruh masing-masing variabel independen terhadap variabel dependen dengan menguji koefesien variabel tersebut. Uji koefisien determinasi digunakan untuk mengukur seberapa jauh kemampuan model dalam menerangkan variasi variabel independen terhadap variabel dependen. Berdasarkan hasil pengujian koefisien determinasi pada tabel diatas, menunjukkan bahwa nilai R Square sebesar 0,262 yang artinya bahwa variabilitas variabel dependen yang dapat dijelaskan oleh variabel independen yaitu earning per share (EPS) dan price book value (PBV) dalam penelitian ini adalah sebesar 26,2\%, sedangkan sisanya 73,8\% dijelaskan oleh variabel-variabel lain di luar model penelitian.

Penelitian ini dilakukan dengan menggunakan sampel penelitian dari 8 perusahaan yang termasuk Industri Retail di Bursa Efek Indonesia pada periode 2013-2016. Adapun tujuan dari penelitian ini adalah untuk mengukur dan mengetahui seberapa besar pengaruh earning per share (EPS) dan price book value (PBV) baik secara simultan ataupun secara parsial pada Industri Retail yang terdaftar di Bursa Efek Indonesia (BEI) selama periode 2013-2016. Pengujian hipotesis yang dilakukan terhadap analisis regresi menunjukkan ada tidaknya pengaruh antara variabel independen yaitu earning per share (EPS) dan price book value (PBV) yang dimasukkan kedalam model regresi dengan variabel dependen yaitu harga saham. Berdasarkan uji hipotesis yang dilakukan diperoleh hasil sebagai berikut: Berdasarkan hasil pengujian hipotesis (uji F) pada model regresi secara simultan diperoleh nilai signifikan sebesar 0,012>0,05 (taraf signifikasi). Selain itu dapat dilihat juga dilihat hasil perbandingan antara $f_{\text {hitung }}$ dan $f_{\text {tabel }}$ yang menunjukan $f_{\text {hitung }}$ sebesar 5,153 
sedangkan $f_{\text {tabel }}$ sebesar 3,52. Dari hasil tersebut terlihat bahwa $f_{\text {hitung }}>f_{\text {tabel }}$ yaitu 5,153 $>$ 3,52 maka dapat disimpulkan bahwa secara simultan variabel independen earning per share (EPS) dan price book value (PBV) berpengaruh signifkan terhadap variabel dependen harga saham. Hal ini menunjukkan bahwa harga saham yang terjadi pada Industri Retail dapat dipengaruhi oleh earning per share (EPS) dan price book value (PBV). Hasil penelitian ini didukung oleh penelitian sebelumnya yaitu penelitian yang lakukan oleh Saryadi dkk (2013) yang menunjukkan hasil bahwa earning per share (EPS) memiliki pengaruh signifikan terhadap harga saham. Berdasarkan hasil pengujian secara parsial menyatakan bahwa earning per share (EPS) memiliki pengaruh secara signifikan terhadap harga saham pada industri retail yang terdaftar di Bursa Efek Indonesia karena $t_{\text {hitung }}$ lebih besar dari $t_{\text {tabel }}(3.159>2,048)$. Koefisien regresi earning per share (EPS) sebesar 0,528 memberikan arti positif terhadap harga saham. ini menunjukkan bahwa earning per share (EPS) mempunyai hubungan yang searah dengan harga saham. Bahwa setiap kenaikan earning per share (EPS) satu satuan maka harga saham akan naik sebesar 52,8\%. Oleh sebab itu, perusahaan harus terus mendorong nilai earning per share (EPS) karena dapat meningkatkan harga saham. Pengujian secara parsial menyatakan bahwa price book value (PBV) tidak memiliki pengaruh yang signifikan terhadap harga saham pada Industri Retail yang terdaftar di Bursa Efek Indonesia karena $t$ hitng lebih kecil dari $t_{\text {tabel }}(0,113<2,048)$. koefisien regresi sebesar 0,018 bahwa price book value (PBV) berpengaruh negatif terhadap harga saham. Hal ini menunjukkan bahwa dengan penambahan price book value (PBV) sebesar 1\% maka akan menurunkan harga saham sebesar 1,8\%. Oleh sebab itu, perusahaan harus berhati-hati atas kenaikan nilai price book value (PBV) karena dapat menurunkan harga saham. Penelitian ini juga bertolak belakang dengan penelitian Suaryana dan Dewi (2009) membuktikan bahwa price book value (PBV) berpengaruh signifikan terhadap harga saham. Nilai koefisien determinasi ( $R$ Square) sebesar 26,2\%, hal ini berarti earning per share (EPS) dan price book value (PBV) mampu menjelaskan Harga Saham sebesar 26,2\% sedangkan sisanya sebesar 73,8\% dipengaruhi oleh faktor lain diluar penelitian ini.

\section{SIMPULAN}

Berdasarkan hasil analisis diatas maka peneliti dapat menarik kesimpulan sebagai berikut:

1. Hasil pengujian secara simultan membuktikan bahwa model regresi secara simultan variabel independen Earning Per Share (EPS) dan Price Book Value (PBV) berpengaruh signifikan terhadap variabel dependen harga saham pada industri retail periode 2013-2016.

2. Hasil penelitian secara parsial membuktikan bahwa variabel Price Book Value (PBV) tidak berpengaruh signifikan terhadap variabel dependen harga saham sedangkan Eaning Per Share (EPS) berpengaruh signifikan terhadap variabel dependen harga saham.

\section{DAFTAR PUSTAKA}

Adisetiawan, R., 2015, Simultan Jangka Panjang antara Fluktuasi Indeks Harga Saham, Tingkat Inflasi, Suku Bunga dan Kurs IDR/USD Terhadap Return Saham Reksadana di Indonesia, EKSIS: Jurnal Ilmiah Ekonomi dan Bisnis, 6(1), 5-17

Adisetiawan, R., dan Asmas, Denny., 2012, Hubungan EVA dan MVA sebagai Alat Pengukur Kinerja Perusahaan Serta Pengaruhnya Terhadap Harga Saham, Jurnal Ilmiah Universitas Batanghari, 12(1), 12-18

Ardiyanto, Ari. (2007). Pengaruh Rasio Earning Per Share (EPS), Price Earning Ratio (PER) dan Return On Asset (ROA) Terhadap Harga Saham Sektor Perbankan di Bursa Efek Indonesia (BEI) periode 20072009. Skripsi, Universitas Negeri Malang.

Arifin, Ali. (2004). Membaca Saham. Penerbit Andi. Yogyakarta.

Aryanti, Tommy. (2012). Pengaruh Return On Equity (ROE) dan Earning Per Share (EPS) Terhadap Harga

Saham Pada Perusahaan Manufaktur Sektor Otomotif yang Terdaftar di Bursa Efek Indonesia (BEI)

Periode 2012-2014. Skripsi, Fakultas Ekonomi Universitas Komputer Indonesia.

Berman, Barry. (2001). Retail Management A Strategic Approach. Prentice Hall, New Jersey.

Budiman. (2013). Pengantar Manajemen Keuangan. PT Raja Grafindo Persada. Jakarta.

Darmadji, Tjiptono. (2006). Pasar Modal DiIndonesia, Edisi 3, Penerbit : Salemba Empat.

Pengaruh Earning Per Share (EPS) dan Price Book Value (PBV) terhadap Harga Saham pada Industri Retail yang Terdaftar di BEI Periode 2013-2016 
Desmawati, Arum. (2007). Pengaruh Earning Per share (EPS), Return On Equity (ROE), dan Debt Equity Ratio (DER) Terhadap Harga Saham Perusahaan Manufaktur di Bursa Efek Indonesia (BEI) Tahun 2007-2011. Skripsi, Universitas Muhammadiyah Surakarta.

Effendi, Usman. (2014). Asas Manajemen, Jakarta: PT. Raja Grafindo Persada.

Fahmi, Irham. (2014). Pengantar Manajemen Keuangan. Bandung: Alfabeta.

Gilbert, David. (2003). Retailing Market Management. 2th Edition. England, Endinburgh Gate: Pearson Educated Limited.

Hendy. (2008). Pasar Modal. Edisi Pertama, Jakarta.

Istijanto. (2009). Metodologi Penelitian Bisnis. Jakara: PT. Gramedia Pustaka.

Jati, dkk. (2012). Pengaruh Earning Per Share (EPS), Price Earning Ratio (PER) dan Book Value Share (BVS)

Terhadap Harga Saham di Bursa Efek Indonesia (BEI) Tahun 2012-2014. E-Jurnal Akuntansi Vol.17.2.

Fakultas Ekonomi Universitas Udayana.

Kasmir. (2008). Bank dan Lembaga Keuangan Lainnya. Jakarta: Raja Grafindo. Persada. (2012). Analisis Laporan Keuangan. Raja Grafindo Persada, Jakarta.

Kuncoro, Mudrajat. (2013). Metode Riset Untuk Bisnis dan Ekonomi. Edisi ke-4. Jakarta :Erlangga.

Mahmud M, Hanafi. Dan Abdul Halim. (2007). Analisa Laporan Keuangan. Yogyakarta: UUP YKPN.

Moeljadi. (2006). Manajemen Keuangan. Pendekatan Kuantitatif dan Kualitatif, Edisi Pertama. Bayu Media Publishing, Malang.

Rusdin. (2007). Pasar Modal. Edisi Pertama, Bandung: Alfabeta.

Sartono, Agus. (2001). Manajemen Keuangan Teori dan Aplikasi. Edisi 4, BPEE, Yogyakarta.

Saryadi, dkk. (2013). Pengaruh Earning Per Share (EPS), Price Earning Ratio (PER), Debt Equity Ratio (DER), Return On Equity (ROE) Terhadap Harga Saham Pada Perusahaan Sektor Pertambangan Yang Terdaftar di Bursa Efek Indonesia (BEI) Tahun 2010-2012. Jurnal sosial dan politik, Universitas Diponegoro.

Suad, Husnan. (2009). Dasar-dasar Teori Portofolio dan Analisis Sekuritas. Yogyakarta.

Suaryana.dan Dewi. (2009). Pengaruh Earning Per share (EPS), Debt Equity Ratio (DER) dan Price Book Value (PBV) Terhadap Harga Saham di Bursa Efek Indonesia (BEI) Tahun 2009-2011. E-Jurnal Akuntansi Vol. 4.12013 Universitas Udayana.

Sugiyono. (2017). Metode Penelitian Kuantitatif, Kualitatif dan R\&D. Bandung: Alfabeta.

Sunyoto. (2013). Teori, Kuesioner dan Proses Analisis Data Perilaku Organisasional. Penerbit : Caps. Tandelilin, Edaurdus. (2010). Manajemen Investasi dan Portofolio. Edisi Pertama, Yogyakarta: Kanisius. Undang-Undang Nomor : 8 (1995). Pasar Modal. Jakarta.

Utari, Dewi dkk. (2014). Manajemen Keuangan. Mitra Wacana Media. Jakarta. 